\title{
Abusive Tax Shelters And Government Misconduct
}

\author{
William A. Bottiglieri, MBA, CPA, JD, Iona College, USA \\ Huldah A. Ryan, Ph.D., Iona College, USA \\ Andrew S. Griffith, DBA, EA, CIA, CFE, Iona College, USA
}

\begin{abstract}
Congress reacted quickly to the accounting profession's involvement in the Enron/Tyco International financial collapses in 2001. The Sarbanes-Oxley Act of 2002 was enacted and the Securities and Exchange Commission promulgated new reporting regulations aimed at preventing such losses in the future. A more remote effect occurred a year later in 2003 when Congress enacted sweeping reforms affecting the tax shelter industry. Congress targeted accounting firms and related professionals who created, marketed and sold abusive tax shelters. While the culpability of these professionals was clear the resulting criminal prosecutions against some of the accounting professionals were tainted by an overzealous prosecution which relied on unconstitutional tactics to obtain convictions.
\end{abstract}

Keywords: Tax Shelter; Government Misconduct

\section{INTRODUCTION}

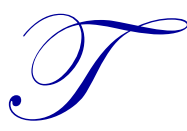

he ethical standards of the legal and accounting profession have been pushed, prodded, bent, and in some cases broken for enormous monetary gain. ${ }^{1}$

And so began the 2003 U.S. Senate hearings investigating the roles of accountants, attorneys, and other financial professionals in abusive tax shelters. The Permanent Subcommittee on Investigations had uncovered how those shelters worked; how they were first structured to avoid scrutiny by the Internal Revenue Service and then marketed to potential investors. The emphasis of the committee's report was unique in that most of the tax shelter products which were investigated were not technically illegal, yet they were found to be ethically questionable in that they demonstrated a deliberate effort on the part of the participants to avoid detection and scrutiny by the Internal Revenue Service. Countless Americans, "average working families would bear the brunt of lost (tax) revenues so that a handful of rich lawyers, accountants, and their clients could manipulate legitimate business practices to make a profit." 2

In this article we review the government case against KPMG and some of its partners and managers who were accused of developing and promoting tax shelters, which deprive the government of tax revenues. The indictment focused on KPMG's strategies in intentionally designing these tax shelters to avoid detection by the IRS. Tax shelters are generally tax-savings devices but can range from tax planning that is allowable and even encouraged, such as retirement plans like $401(\mathrm{~K})$ and IRA accounts, to abusive tax shelters such as business arrangements which take advantage of ambiguities or inconsistencies in the tax code and the establishment and use of off-shore companies to avoid or evade taxes.

\footnotetext{
${ }^{1}$ Opening remarks, U.S. Senator Norm Coleman, MN; U.S. Tax Shelter Industry: The Role Of Accountants, Lawyers, And Financial Professionals; Hearings before the Permanent Subcommittee On Investigations of the Committee On Governmental Affairs United States Senate; $108^{\text {th }}$ Congr. 2 (2003)

${ }^{2}$ Id, at 4
}

(C) 2012 The Clute Institute http://www.cluteinstitute.com/ 
Section I discusses the hearings by The Senate Committee on Governmental Affairs which investigated and uncovered these KPMG strategies, while Section II examines the improper, aggressive and ultimately self-defeating tactics employed by the government in the criminal prosecution of a tax case against certain KPMG associates which ultimately caused the case to be dismissed in substantial part. Section III discusses the outcome of the case and the continuing Congressional scrutiny into these abusive strategies.

\section{THE SENATE HEARINGS}

In 2001 the accounting profession drew much attention because of the well known, dishonest and fraudulent business practices conducted by Enron, Global Crossing, Tyco International and other companies. Financial failures, bankruptcies and criminal prosecutions followed, including the indictment of Enron's auditors, Arthur Andersen LLP, which resulted in the dissolution of the firm. Not long after, the President established a corporate fraud task force under the auspices of the Office of the United States Attorney General. At the same time the Internal Revenue Service began investigating tax shelters and targeted the accounting firm of KPMG for its role in structuring and marketing certain abusive tax shelters. The Senate Committee on Governmental Affairs through its Permanent Subcommittee on Investigations then began a similar investigation, and subpoenaed several KPMG partners and former partners to testify.

As indicated by Senator Coleman's opening remarks the firm did not receive a warm welcome. At one point during the proceedings, Senator Carl Levin of Michigan prompted a witness to "try an honest answer" ${ }^{\text {" }}$ At this hearing, it was acknowledged that given the complexity of the tax law, the interpretation of the Internal Revenue Service is not legally binding. While it serves to memorialize the government's interpretation of the Code, it is only an opinion and taxpayers have every right to disregard this interpretation provided they have a reasonable basis for doing so. However, as the government's enforcement agency, the Internal Revenue Service has the right to challenge any interpretation that it does not agree with. Such challenges might ultimately result in a suit that would be settled by the interpretation of a court. Before being able to challenge the interpretation of a taxpayer however, the IRS must first be aware of a taxpayer's position. The committee uncovered evidence that certain strategies employed by KPMG in its design of the subject tax shelters were intended to avoid detection by the IRS and further that the accounting firm had knowingly circumvented certain reporting and disclosure requirements which deprived the IRS of the opportunity to challenge them. In addition, while lauding the accounting and legal professions for generally holding themselves up to high ethical standards, it was the clients of these professionals who would suffer by placing their trust and confidence in individuals who are not upholding these ethical standards.

\section{TAX SHELTERS}

Tax shelters are generally strategies which permit taxpayers to shelter income from tax by taking advantage of allowable tax deductions or by having their income taxed at lower than ordinary tax rates. Although not generally referred to as such, Individual Retirement Plans (IRAs) and 401(K) accounts which enable individuals to invest pretax earnings as part of their pension savings plans are types of tax shelters. Home ownership can also be viewed as a type of tax shelter because of the allowable deductions for mortgage interest and real estate taxes as well as the tax credits available for certain types of home improvement expenditures such as those using solar energy. Congress encourages these types of activities by providing for the related tax benefits. However, tax savings resulting from innovative tax-planning strategies that wealthy individuals and companies use to take advantage of loopholes in the tax system run counter to Congressional intent.

In Internal Revenue Code Section 6662, a tax shelter is defined as a "partnership or other entity, an investment plan or arrangement, or any other plan or arrangement, if a significant purpose of such partnership, entity, plan, or arrangement is the avoidance or evasion of Federal income tax". They include measures aimed at offsetting income from one source with losses from another source, manipulating income (generally subject to tax rates as high as $35 \%$ ) as capital gains (which are subject to the more favorable $15 \%$ rate), or transferring gains offshore in order to minimize taxes. Accounting firms aggressively promoted these types of tax shelters, especially in the 1990s, because of the substantial fees that they generated. These were abusive tax shelters which did not

\footnotetext{
${ }^{3}$ Id at 43
} 
necessarily generate income; instead they were created and structured primarily to maximize the amount of income that could be deducted for tax purposes, and they cost the government billions of dollars of lost revenues each year. Examples are the BLIPS (Bond-Linked Issue Premium Structure), FLIPS (Foreign Leveraged Investment Programs), and OPIS (Offshore Portfolio Investment Strategy) shelters, which allow wealthy clients with vast capital gains to generate substantial capital and ordinary losses instead, in order to eliminate or drastically reduce taxable income. For instance, a taxpayer with a BLIP, would borrow money from an offshore bank to invest in foreign currency sold by the same bank. When the value of the currency declines, the taxpayer could then sell the currency back to the bank and claim a tax loss on the transactions.

The nature of the tax shelter industry had changed significantly over the recent past. Legal and accounting professionals had formerly been sought for tax planning advice but it seemed that certain professionals were now developing complex schemes and were marketing these schemes not only to their clients, but also to the general public in mass marketing efforts. These included a massive telemarketing center maintained by KPMG staff with individuals trained to make cold calls to find buyers for specific tax products.

Evidence at the hearings also disclosed that KPMG refused to follow the advice of some of its own professionals within the firm to register certain of its tax products as tax shelters as required by the Internal Revenue Service. Finally, the hearings uncovered the willingness of many other professionals and institutions such as banks, investment advisory firms and law firms to join in the structuring of these complex financial instruments and tax shelters which added to the illusion of economic substance and added an appearance of legitimacy.

As a result of these hearings, several provisions of the Internal Revenue Code were enacted in an attempt to curtail the attempts at abuse by these tax professionals. Some of these newly enacted provisions are as follows:

- $\quad$ IRC Section 6707A imposes penalties of up to $\$ 200,000$ for failure to disclose certain elements of tax shelter activity on related tax returns; this penalty would be subject to administrative review but not judicial review. In addition, if the penalty is imposed on an entity which is required to file reports with the SEC, the fact that a penalty was imposed would have to be reported to that agency;

- IRC 6662A imposes accuracy-related penalties of up to $30 \%$ of the understatement of tax relating to a tax shelter investment;

- $\quad$ IRC 7525 eliminates the common law protection of confidentiality privileges for any communications relating to the promotion of participation in tax shelters;

- IRC 6111, as amended, creates a new designation, referred to as a "material advisor", for those who provide assistance or advice in organizing, promoting, selling or carrying out any reportable tax shelter transaction and imposes disclosure requirements regarding these transactions; and

- IRC 6112, as amended, requires material advisors to maintain advisee/client lists available for inspection by the government.

\section{GOVERNMENT MISCONDUCT IN THE KPMG CASE}

Shortly after the spate of financial reporting deficiencies which contributed to the collapse of Enron and other public corporations in 2001 and the congressional hearings which followed, KPMG was involved in a related suit in which several of its partners and former partners were indicted for alleged violations of Internal Revenue Service regulations regarding tax shelters ${ }^{4}$. The defendants moved to dismiss the indictment on the grounds that both their $5^{\text {th }}$ amendment constitutional right to a fair trial and their $6^{\text {th }}$ amendment constitutional right to counsel were violated. The central theme of these alleged constitutional violations was the misconduct of the government in exerting influence over the KPMG firm to cut off funds it would have made available to these defendants to pay for their legal defense of this action. The government's position was that in certain cases the payment of legal fees by a company whose employees were charged with a crime would be indicative of an obstruction scheme, and would prevent these firms from cooperating with the government. It was alleged by these defendants that the government's action effectively cut off their right to the counsel of their choosing and thus would prevent them from receiving a fair trial.

\footnotetext{
${ }^{4}$ US v Jeffrey Stein et al, 435 F supp. 2d 330, US District Court for the Southern District of New York

(C) 2012 The Clute Institute http://www.cluteinstitute.com/
} 
Several of the defendants in this action had previously testified before the Senate hearings and the IRS proceedings concerning tax shelters. The defendants who were still active partners at KPMG were asked to leave the firm and were granted very generous severance packages, including being promised indemnification against any legal costs incurred by reason of this pending action. This had been a longstanding practice of KPMG and in fact, many companies followed this policy of reimbursing an employee for legal expenses incurred in connection with their employment.

In pre-trial discussions, the government negotiated with counsel for KPMG. The firm, although not a defendant, retained counsel in an attempt to negotiate a favorable settlement of the entire matter and avoid being indicted itself. During these negotiations the prosecution indicated that the government might view the payment by KPMG of employee legal fees as rewarding misconduct ${ }^{5}$. The message delivered, and clearly understood by KPMG, was that its adherence to its longstanding practice of paying employee legal fees might hurt it in its position regarding the government's decision to possibly indict the firm. The court's view of this not so subliminal message was that although government representatives "did not say in so many words that it did not want KPMG to pay legal fees, no one at the meeting could have failed to draw that conclusion" .

Further along in these discussions, KPMG relented to this government pressure and made the decision to abandon its longstanding practice of reimbursing employees legal fees. Its newly adopted position was that it did not see that it had any binding legal obligation to pay these fees. The ultimate agreement that was reached between KPMG and the government was that it would put a limit on legal fees and would condition the payment for any given employee on that employee cooperating fully with the government in its investigation. One indication of the effect of the government's influence on KPMG and, indirectly, on the defendants' ability to mount a defense, was a statement by counsel for KPMG to the attorney for one of the employee-defendants. KPMG would pay the defendant's legal fees so long as the defendant cooperated with the government and did not, for example, invoke her privilege against self-incrimination under the $5^{\text {th }}$ amendment by refusing to testify ${ }^{7}$. The government's influence on the defendants' ability to retain counsel was thus very clear and the court did not like it.

The agreement between KPMG and its employees who were subject to investigation was that unless the employees cooperated with the government in a prompt and truthful manner, legal fees would cease immediately, as they would if an indictment were in fact issued against an individual. The government took full advantage of its controlling position and repeatedly notified KPMG counsel when any of its personnel failed to comply with government demands. This notification resulted in counsel for KPMG reminding the attorney for the non-compliant employee that payment of legal fees would be terminated unless the employee cooperated with the government in its investigation. KPMG did not make any effort to hide its motivation in cooperating with, and in fact being controlled by, the government; its only real concern was avoiding an indictment against the firm even at the cost of pressuring its employees to cooperate, sometimes against their own personal interests ${ }^{8}$.

Ultimately KPMG benefited from assisting and cooperating with the government. In August 2005, KPMG and the government entered into a Deferred Prosecution Agreement under which it agreed to admit wrongdoing, would pay a substantial fine, and accept an indictment on one charge, which it was agreed, would later be dismissed. KMPG thus avoided criminal conviction.

In making its determination in dismissing these indictments, the court thoroughly reviewed many of the notes of meetings and discussions among the government, KPMG counsel, and counsel for various defendants. Its conclusions were easy to reach. Threats were inherent in the government's relationship with all parties concerned. It wielded significant power in its ability to indict KPMG and used this power to affect the legal representation which was available to KPMG's employees and former employees. In other words, it stacked the deck against these defendants. The government's actions subverted the defendants' right to be represented by an attorney of their own choosing free of any government regulation or threats, and unfettered by any restrictions imposed by its adversary.

\footnotetext{
${ }^{5}$ Id at 29

${ }^{6} \mathrm{Id}$ at 32

${ }^{7}$ Id at 33

${ }^{8}$ Id at 44 
"In short, fairness in a criminal proceeding requires that the defendant be firmly in the driver's seat, and that the prosecution not be a backseat driver"'. The government's action here deprived the defendants of due process in denying them their fundamental right to protection of liberty and justice.

The court further found that there was more than a mere procedural error in this case, which might or might not affect the proceeding. The acts committed by the government were so pervasive that they were considered structural defects in that the defendants were constructively denied counsel for the entire proceeding. The court thus found that the entire proceedings were contaminated by the government's conduct and that there was no need to show specific prejudice. The government's interference in these defendants' ability to mount a defense created the appearance of impropriety, which diminished the faith in the fairness of the criminal justice system in general ${ }^{10}$.

The court agreed with the defendants' claim that they were denied their rights to choose their own counsel and receive a fair trial, and granted their motion to dismiss the indictment on these grounds. The defendants' motion for monetary sanctions against the government was however denied.

On appeal the appellate court found of the prosecution's conduct that "Their deliberate interference with the defendants' rights was outrageous and shocking in the constitutional sense because it was fundamentally at odds with two of our most basic constitutional values -- the right to counsel and the right to fair criminal proceedings." In affirming the dismissal of the charges, the court stated that it " has reached this conclusion only after pursuing every alternative short of dismissal and only with the greatest reluctance. This indictment charges serious crimes. They should have been decided on the merits as to every defendant... But there are limits on the permissible actions of even the best prosecutors." 12

\section{SUMMARY AND DISCUSSION}

The inquiry into the roles of professionals in the tax shelter industry did not end with the $108^{\text {th }}$ Congressional session. The Senate Committee Report of the $109^{\text {th }}$ session of Congress stated in its introduction:

The abusive tax shelters investigated by the Subcommittee were complex transactions used by corporations or individuals to obtain substantial tax benefits in a manner never intended by the Federal tax code. While some of these transactions may have complied with the literal language of specific tax provisions, they produced results that were unwarranted, unintended, or inconsistent with the overall structure or underlying policy of the Internal Revenue Code. These transactions had no economic substance or business purpose other than to reduce taxes. Abusive tax shelters can be custom-designed for a single user or prepared as a generic tax product sold to multiple clients. The Subcommittee investigation focused on generic abusive tax shelters sold to multiple clients as opposed to a custom-tailored tax strategy sold to a single client. ${ }^{13}$

The committee also reported in its Findings and Recommendations that “...numerous respected members of the American business community were heavily involved in the development, marketing, and implementation of generic tax products whose principal objective was to reduce or eliminate a client's U.S. tax liability. These tax shelters required close collaboration between accounting firms, law firms, investment advisory firms, and banks." ${ }^{14}$ The result of this session of Congress was to amend certain of the reporting and penalty provisions enacted by the previous Congressional session.

\footnotetext{
${ }^{9}$ Id at 71

${ }^{10}$ Id at 118

11495 F. Supp. 2d 390, at 414

12495 F. Supp. 2d 390, at 427

${ }^{13}$ The Role Of Professional Firms In The U.S. Tax Shelter Industry;

R E P O R T prepared by the Permanent Subcommittee On Investigations

Of The Committee On Homeland Security And Governmental Affairs

United States Senate; $109^{\text {th }}$ Congr. 2 (2005)

${ }^{14} \mathrm{Id}$
}

(C) 2012 The Clute Institute http://www.cluteinstitute.com/ 
The focus of this study expanded beyond the government's involvement in the tax shelter industry as investigators and legislators. Its subsequent involvement in this same industry was that of prosecutors. Here we found improper measures taken by federal prosecutors in their attempts to procure a conviction. These improprieties were so pervasive that their ultimate effect was to deny the defendants due process and they suffered the severest of sanctions, dismissal of the charges.

Several issues are raised in this study. The first issue is raised in relation to agency theory, with the public as the principal and the government as the agent. The actions of the agent, in this case, the federal prosecutors, were not aimed at benefiting the principal. They had their own agenda; to win the case at any cost. However, the curtailment of the defendants' constitutional rights was the antithesis of promoting the objectives of the principal.

The second issue relates to the legal rights of the individual, which have both Utilitarian and Kantian foundations. From a Utilitarian context, the actions of the government prosecutors were indicative of an abuse of power and a violation of the trust and credibility that should be an essential element of the judicial system. Their role should be to promote the public interest and their activities should be geared towards upholding the public good. As public officials, they should have been aware of the lines that should not be crossed. Instead, they were overzealous in their actions against the defendants; they disregarded their duty in the quest for a guilty verdict; and thereby, wrought harm to the defendants. This should be evaluated in relation to the benefits that could have resulted from a guilty verdict, which includes future potentially higher tax revenues for the government, while at the same time, serving as a deterrent to future accountants, financial professionals, and attorneys from attempting to take advantage of the tax loopholes that spawned the tax shelters in the first place.

From a Kantian/Deontological perspective, the actions of the prosecutors resulted in a violation of the rights of the defendants, when they were denied access to counsel and a fair trial. A commentary in the Wall Street Journal in July 2007 noted the duty of the government to respect the rights of citizens involved in criminal activities. Whenever it fails in its duty, it surrenders its legitimacy that gives it the power to try people for crimes that they commit.

The third issue of note is the philosophical contradictions that arise in the case against KPMG. It was clear from the outcome that the actions of the prosecutors were harmful to the defendants. However, individuals sometimes are faced with the conflict of doing what society deems to be the right thing (Kantian Deontology), while at the same time winning by any means (Machiavellianism). The prosecutors were faced with the task of acting on principle for the public good while at the same time serving the interest of the public (Bailey, 1965). They had to get a conviction, even if it meant harming others in the process. These issues lend themselves to the dilemma faced by public officials as they try to balance the elements of responsibility, efficiency, accountability, and morality.

Finally, the case highlights the need for punishment and/or sanctions against public officials who abuse the power with which they are entrusted. The partners and employees who were denied 'due process' should be able to claim monetary damages or some other kind of retribution from the individuals who violated their constitutional rights. In addition, if the media focus on incidences of government misconduct was as relentless as their focus on the actions of celebrities, the public would become more informed about the individuals in government employment, and the public scrutiny would serve as a deterrent to bad behavior by government officials.

\section{AUTHOR INFORMATION}

William A. Bottiglieri, MBA, CPA, JD, is a Professor in Accounting at Iona College, New Rochelle, New York and is in private practice as an attorney and tax accountant. E-mail: wbottiglieri@iona.edu (Corresponding author)

Huldah Ryan, Ph.D., is a Professor in Accounting at Iona College, New Rochelle, New York.

Andrew S. Griffith, Ph.D., DBA, EA, CIA, CFE, is an Assistant Professor of Accounting at Iona College. 


\section{REFERENCES}

1. Bailey, S. K., 1965. The Relation Between Ethics and Public Service, in R. C. Martin (Ed.), Public Administration and Democracy: Essays in honor of Paul Appleby Syracuse, NY: Syracuse University Press, pp. 282-298.

2. Brady, F. and D. Hart, 2006. An Aesthetic Theory of Conflict in Administrative Ethics, Administration \& Society, March, Vol. 38: 1, pp. 113-134.

3. Curry, P., Hill, C., and F. Parisi, 2007. Creating Failures in the Market for Tax Planning, Virginia Tax Review, Spring 26: (4), pp. 943-969.

4. Hardin, R. 2004. Trust and Trustworthiness. Russel Sage Paperback ed.

5. Hickman, K. 2007. Of Lenity, Chevron, and KPMG, Virginia Tax Review, Spring 26: (4), pp. 905-937.

6. Jensen, M. and W. Meckling, 1976. Theory of the Firm: Managerial Behavior, Agency Costs, and Ownership Structure, Journal of Financial Economics 3, 305-360.

7. Kahn, W. A., 1990. Toward an Agenda for Business Ethics Research, Academy of Management Review 15, (2): 311-328.

8. Warren, M. 1999. Democracy Theory and Trust, in Mark E. Warren ed., Democracy and Trust, pp. 310345 .

9. Weisbach, D. A. 2002. An Economic Analysis of Anti-Tax-Avoidance Doctrines, American Law and Economics Review, Vol. 4, 1, pp. 88- 


\section{NOTES}

